\title{
A NEW SPECIMEN OF STRATIOTOSUCHUS MAXHECHTI (BAURUSUCHIDAE, CROCODYLIFORMES) FROM THE ADAMANTINA FORMATION (UPPER CRETACEOUS), SOUTHEASTERN BRAZIL
}

\author{
ANDRÉ EDUARDO PIACENTINI PINHEIRO, REINALDO J. BERTINI \\ Núcleo de Evolução e Paleobiologia de Vertebrados, IGCE, DGA, UNESP, Campus Rio Claro, 13506-900, Rio Claro, SP, Brazil. \\ paleolones@yahoo.com.br, rbertini@rc.unesp.br \\ MARCO BRANDALISE DE ANDRADE \\ Department of Earth Sciences, Faculty of Sciences, University of Bristol, BS8 1RJ, Bristol, UK.marcobranda@yahoo.com.br
}

\section{RAFAEL GIÓIA MARTINS NETO}

ICB, DZ, Campus Universitário, Martelos, UFJF, 36036-900, Juiz de Fora, MG, Brazil.martinsneto@terra.com.br

\begin{abstract}
This is a report about the second occurrence and description of the third specimen of Stratiotosuchus maxhechti (Baurusuchidae, Crocodyliformes) from the Bauru Basin, Upper Cretaceous of southeastern Brazil. The material was found in the typical reddish, fine-grained sandstone from the Adamantina Formation, Bauru Group, Monte Alto County, São Paulo State. These strata are considered to be Campanian-Maastrichtian in age. It is the second skull of Stratiotosuchus maxhechti recovered where the choanal region and the skull-mandible articulation is preserved. The holotype of this species comes from the Adamantina Formation from southwestern São Paulo State, while this new specimen comes from its northern-central region, making possible biochronological and paleoecological correlations among different geographically distant stratigraphic horizons within the Bauru Basin. The main osteologic contributions from this new specimen are the surangular taking part in the skull/mandible articulation and the presence of a relatively well-preserved choanal region, which are not seen in the holotype, furthering the knowledge of Stratiotosuchus maxhechti. Based on the features of this new specimen, an emended diagnosis is provided.
\end{abstract}

Key words: Crocodylomorpha, Baurusuchidae, Adamantina Formation, Upper Cretaceous, Stratiotosuchus.

\begin{abstract}
RESUMO - Esta contribuição trata de segunda ocorrência e descrição do terceiro espécimen de Stratiotosuchus maxhechti (Baurusuchidae, Crocodyliformes) na bacia Bauru, Cretáceo Superior do sudeste do Brasil. O material foi encontrado no típico arenito avermelhado fino da Formação Adamantina, Grupo Bauru, Município de Monte Alto, Estado de São Paulo. Estes depósitos são considerados de idade Campaniano-Maastrichtiano. Constitui o segundo crânio de Stratiotosuchus maxhechti resgatado até o momento e apresenta as porções das coanas, e da articulação crânio-mandíbula, bem preservadas. O holótipo desta espécie provém da Formação Adamantina do sudoeste do Estado de São Paulo, enquanto este novo espécimen procede de sua região centro-norte, possibilitando o estabelecimento de significativas correlações biocronológicas e paleoecológicas entre os horizontes estratigráficos de localidades geograficamente distantes, no âmbito da bacia. As principais contribuições osteológicas deste novo espécimen vem da constatação de que o surangular toma parte na articulação crânio/mandíbula, e a presença de uma relativamente bem preservada região das coanas, aspectos que não são observáveis no holótipo, ampliando o conhecimento sobre Stratiotosuchus maxhechti. Baseado nas características deste novo espécime, é apresentada uma diagnose emendada à espécie.
\end{abstract}

Palavras-chave: Crocodylomorpha, Baurusuchidae, Formação Adamantina, Cretáceo Superior, Stratiotosuchus.

\section{INTRODUCTION}

During the Upper Cretaceous in South America, the Crocodylomorpha fauna comprised mainly basal Mesoeucrocodylia. However, in the northern continents the Eusuchia represented a substantial portion of the Crocodylomorpha faunas. This fact is a consequence of the great influences of the South American geographic isolation on the terrestrial fauna (Riff, 2003). Several Mesoeucrocodylia exhibit a South American distribution (e.g., Sebecosuchia, Notosuchia, Peirosauridae and
Araripesuchus), and are considered lineages endemic to this continent (Gasparini et al., 1991), or at least to Gondwana.

Sebecosuchia were terrestrial Gondwana Upper Cretaceous predators, particularly in South America (Baurusuchus, Cynodontosuchus, Stratiotosuchus, Pehuenchesuchus), Africa (Eremosuchus) and Pakistan (Pabwehshi). These Crocodyliformes survived into the Cenozoic in both South America (Sebecus, Ayllusuchus, Bretesuchus) and Europe (Iberosuchus, Bergisuchus). Cretaceous Sebecosuchia are believed to have occupied niches that in other localities were held by carnivorous dinosaurs (Bertini, 1993; Kellner, 1998). 
During the 1980s, an almost complete Crocodylomorph skeleton was collected, and it was initially believe to be related to the genus Baurusuchus by Campos \& Suarez (1988). This material, one of the best preserved from the Upper Cretaceous of Brazil, came from an Adamantina Formation outcrop, in the municipality of Irapuru, in southwestern São Paulo State (Figure 1). This specimen was later redescribed as a new taxon, Stratiotosuchus maxhechti, by Campos et al. (2001), and included in the Family Baurusuchidae by Riff(2003).

The holotype of Stratiotosuchus maxhechti (DGM 1477$\mathrm{R}$, Figure 2) was not the only specimen found in the city of Irapuru. A second one (MCT 1714-R), composed only of two incomplete femurs, showing the same characteristics and dimensions of the holotype, indicating taxonomic association, was also collected. According to Riff (2003), there is no evidence of specimens originating from the Irapuru region, other than DGM 1477-R and MCT 1714-R.

During 1974, a partially preserved skull and associated mandible were recovered by one of the authors (RGMN) in the Adamantina Formation sandstones around the city of Monte Alto, in northern-central São Paulo State (Figure 1). The material was donated to the collections of the São Paulo State University (Rio Claro Campus) a few years ago, where it is housed (URC R•73). This material comprises a partially preserved skull missing the rostrum, but articulated to the posterior portion of the left mandibular ramus. Some diagenetic deformation processes have fragmented it, mainly in the mandible and palatal regions, and it is dorsoventrally compressed (Figures 3-8).

URC R・73 was recognized as a new specimen of Stratiotosuchus maxhechti mainly by: (i) the morphology of the skull roof and parietal region, especially the structure of the supratemporal fenestrae and the characteristic frontal; (ii) the morphology and same inclination angle of the quadrate and quadratojugal; (iii) the morphological lateral aspect of the quadrate, which shows a deep concavity in the medial area; (iv) the morphology of the exoccipital, with a pair of lateral tuberosities, and the basioccipital V-shaped in ventral view; (v) the morphology of the occipital wall, showing a characteristic supraoccipital shape, with aponeurosis scars due to the attachment of strong neck muscles on its dorsal surface; and (vi) the frontal region showing a pronounced depression on the upper dorsal surface (Figure 8). Although there are differences in size and morphology, when compared to the holotype DGM 1477-R, these distinctions mainly refer to the presence of unfused elements. These disagreements in size and morphology are regarded as ontogenetic, and $\mathrm{URC} \mathrm{R} \cdot 73$ is considered a younger individual.

One of the main contributions of the specimen URC R•73 comes from the preservation of the choanal region and basisphenoid, which are not preserved in the holotype. The choanae have a rhomboidal/subtriangular shape (Andrade et al., 2006), being relatively wide and limited by the palatines, ectopterygoids and pterygoids. A robust median septum is visible crossing longitudinally the choanal opening (Figure 5). Another important aspect is the possibility of biochronological and paleoecological correlations, concerning these distant localities (horizons) of the Adamantina Formation.

\section{MATERIALS AND METHODS}

The new specimen, URC R•73, comprises cranial elements consisting of a reasonably complete skull (posterior half), articulated with a fragment of the left mandibular ramus, isolated dentary fragment and tooth crown. All these remains suffered strong deformation and crushing during diagenetic processes (Figures 3-8).

Dentition terminology and measurements follow Riff \& Kellner (2001) and Smith \& Dodson (2003). The few preserved teeth were checked for characteristics related to the ziphodont morphology, as defined by Langston (1975) and Prasad \& Broin (2002). To ensure appropriate examination of these features, a well preserved isolated tooth crown (Figure 9) from Stratiotosuchus maxhechti was studied by scanning electronic microscopy (SEM). This crown is part of the first preserved dentary tooth, found broken during preparation and reassembled in the dentary after the SEM procedures.

Preparation. The preparation was mechanical, because the rock matrix is friable. The removal of the sediments was relatively easy, and then the material was covered and consolidated with a thin layer of plexi-glue to preserve.

Comparisons. The holotype, DGM 1477-R, is an almost complete specimen; with skull, mandible (partially preserved), major portion of the vertebral column (except distal tail region) and appendicular elements. Despite the general good condition of preservation of the holotype, the choanae and most perichoanal structures are missing (Figure 2). Other Baurusuchidae specimens were also used for comparison, as listed below.

Comparative material. Stratiotosuchus maxhechti, DGM 1477-R, holotype. Stratiotosuchus maxhechti, MCT 1714R. Baurusuchus pachecoi, DGM 299-R. Baurusuchus sp., URP RC - 3 (1), URP RC - 3 (2). Cynodontosuchus rothi, MLP-64-IV-16-25.

Institutional abbreviations. DGM, MCT, Museu de Ciências da Terra, Departamento Nacional de Produção Mineral, Rio de Janeiro; MLP, Museo de La Plata, La Plata; URC, Universidade Estadual Paulista, Rio Claro.

Anatomical abbreviations. an, angular; ar, articular; bs, basisphenoid; $\boldsymbol{b} \boldsymbol{f} \boldsymbol{f}$, basisphenoid additional foramen; bo, basioccipital; bok, basioccipital knob; $\boldsymbol{C h}$, choanae; co, occipital condyle; $\mathbf{d}$, dentary; $\mathbf{d}^{\mathbf{\prime}}\left(\mathbf{8}_{\mathbf{8}} \mathbf{9}^{\text {th }}\right)$, penultimate dentary tooth; d" $\left(9-10^{\text {th }}\right)$, last dentary tooth; ec,ectopterygoid; ex, exoccipital; f, frontal; $\boldsymbol{f a}$, aereum foramen; $\boldsymbol{f} \boldsymbol{c} \boldsymbol{p}$, foramina for posterior carotid vessel; $\boldsymbol{f i}$, intertympanic foramen; $\boldsymbol{F m}$, mandibular fenestrae; $\boldsymbol{F} \boldsymbol{p l}$, palatal fenestrae; $\boldsymbol{f t a}$, anterior temporal foramen; $\boldsymbol{F t}$, infratemporal foramen; $\boldsymbol{f t} \boldsymbol{p}$, posterior temporal foramen; Fts, supratemporal fenestra; fots, supratemporal fossa; $\boldsymbol{f} \boldsymbol{v}$, foramen vago; $\boldsymbol{g s}$, glenoid surface (fossa); j, jugal; le, lateral eustachian opening; ls, laterosphenoid; $\boldsymbol{M}$, foramen magnum; $\boldsymbol{m e}$, external auditory

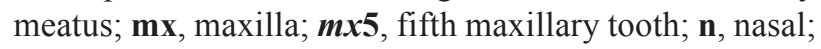


Or, orbit; ot, otoccipital; pa, anterior palpebral; pef, post cranium fragments; $\boldsymbol{p} \boldsymbol{c} \boldsymbol{q}$, cranium, quadrate passage; $\mathbf{p f}$, prefrontal; pl, palatine; pm, premaxilla po, postorbital; pocr, opisthotic paroccipital process; pp, posterior palpebral; pr, parietal; pt, pterygoid; ptb, pterigoydean bullae; ptf, pterigoydean flange wing (transverse process); q, quadrate; qj, quadratojugal; rd sq, descending ramus of the squamosal; sa, surangular; sch, interchoanal septum; so, supraoccipital; soc, supraoccipital crest sq, squamosal; sqr (sqb), squamosal crest forming lateral margin of the supratemporal fossa; XII, foramen for the $12^{\text {th }}$ cranial nerve.

\section{GEOGRAPHIC SETTING AND GEOLOGY}

The fossil elements described here come from an outcrop on the Sérgio Fuzikawa Ranch, in the Bauru Basin, Adamantina Formation, in sediments located northwestern Monte Alto City, in central-northern São Paulo State, Southeast Brazil (Figure 1). It was preserved in a small-tomedium size grained, poorly selected, reddish and reasonably friable sandstone matrix. On the other hand, the holotype and MCT 1714-R come from an outcrop in the Irapuru,area, in southwestern São Paulo State. The occurrences of

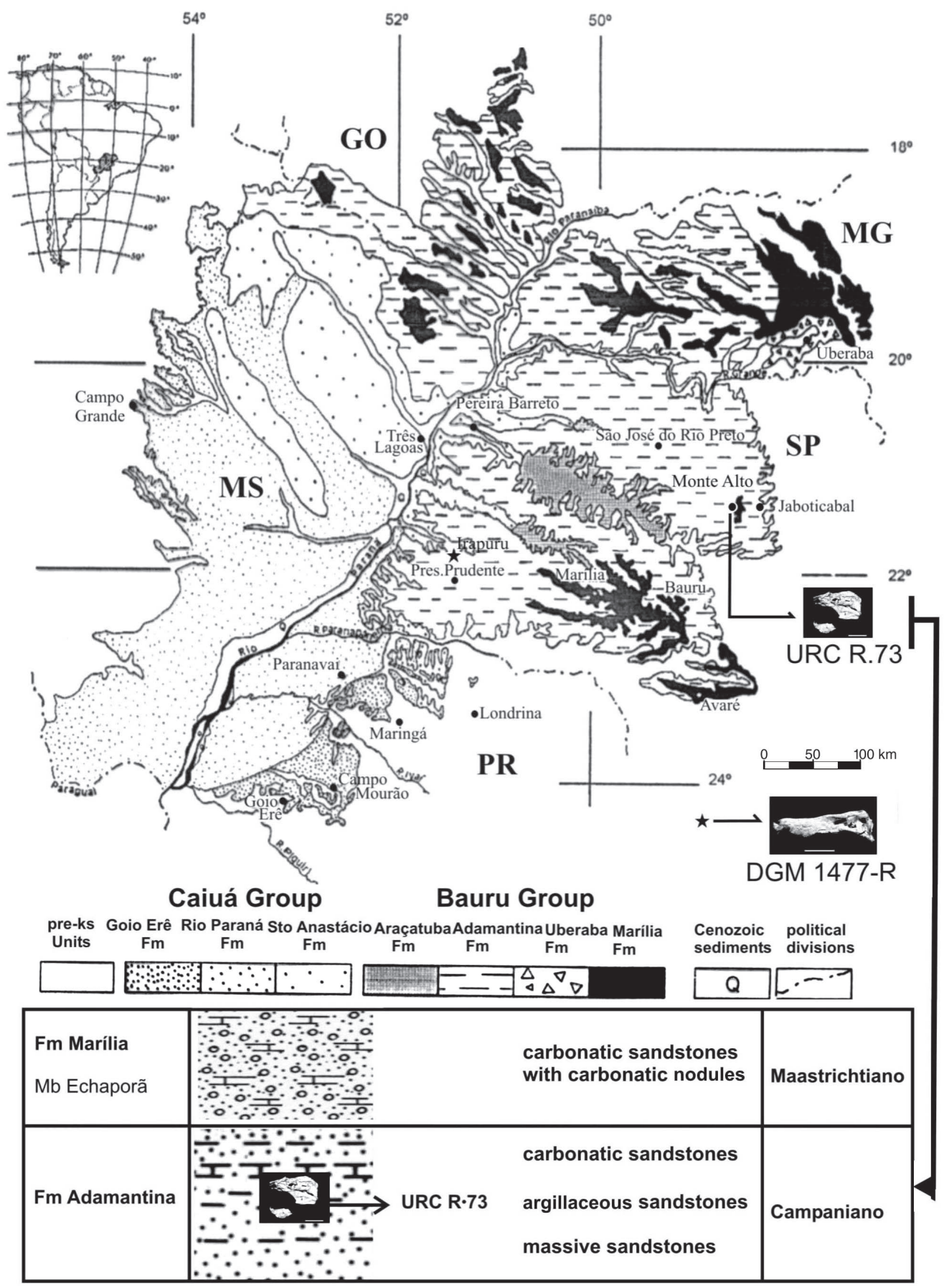

Figure 1. Geographical area of the Bauru Basin in Brazil, with the regions where the specimens URC R・• 73 and DGM 1477-R, were found (modified from Fernandes \& Coimbra, 1994). Below, draft of the stratigraphic section around Monte Alto City, showing URC R・• 73 position. 
Stratiotosuchus, in separated and relatively distant locations of Southeast Brazil is very important, and could have an influence on the interpretation of the paleoenviroment or could result in sampling bias.

The Bauru Basin comprises an area of about $370,000 \mathrm{~km}^{2}$, partially covering the states of São Paulo, Paraná, Mato Grosso do Sul, Minas Gerais and Goiás, in Central and Southeast Brazil (Figure 1), besides some areas in northeastern Paraguay (Bertini, 1993). It was a depression developed during the Gondwanan separation in the Lower Cretaceous, with the accumulation of at least 300 meters of a siliciclastic sequence. It overlays basalts of the Serra Geral Formation (Paraná Basin), from which it is separated by a regional erosive surface (Fernandes \& Coimbra, 1996). Recent data (Bertini et al., 2000; Gobbo Rodrigues et al., 2001; Santucci \& Bertini, 2001) suggest that the Adamantina and Marília formations are Campanian to Maastrichtian in age.

The lithostratigraphic units of the Bauru Basin are divided into the Caiuá and Bauru groups (Fernandes, 1998). The most important fossil localities of this geological sequence are located in the São Paulo and Minas Gerais states (Bertini, 1993), where a rich fauna of fishes, amphibians, testudines, lacertilians, crocodylomorphs, dinosaurs and a mammal have been discovered.

The Adamantina Formation, Campanian-Maastrichtian in age, according to Bertini et al. (2000), Gobbo Rodrigues et al. (2001), Santucci \& Bertini (2001), is the most complex and best geographically represented geological unit from the Bauru Group (Bertini, 1993; Riff, 2003). It shows some interesting regional variations, which led different authors to consider them as facies, lithofacies or members (Bertini, 1993). Lithologically, it is composed of a sequence of fine-grained sandstones, intercalated by mudstones, siltstones and clayish-sandstones (Bertini, 1993). The proposed depositional paleoenvironment is fluvial meandering (Soares et al., 1980) or braided (Fernandes \& Coimbra, 1996), under semi-arid conditions. A progressive increase in aridity, due to the persistence of a hot climate, and topographic heights surrounding the basin, allowed the establishment of alluvial plains, braided rivers and small temporary ponds (Fernandes \& Coimbra, 1996).

\section{SYSTEMATIC PALEONTOLOGY}

\author{
CROCODYLOMORPHA Walker, 1970 \\ CROCODYLIFORMES sensu Benton \& Clark, 1988 \\ MESOEUCROCODYLIA Whetstone \& Whybrow, 1983 \\ SEBECOSUCHIA Simpson, 1937 \\ BAURUSUCHIDAE Price, 1945
}

Stratiotosuchus maxhechti Campos et al., 2001

Diagnosis. Baurusuchidae crocodylomorph with the following features: development of the lateral surface of the jugal; deep depression on the posterodorsal surface of the frontal; lateral margins of the maxilla inflated (from Campos et al., 2001).

Emended diagnosis. Anteroposterior ridge forming a low crest on the dorsal surface of the frontal; frontal does not take part in the supratemporal fossa; detached squamosal posterolateral border in the supratemporal fossa; quadrate and quadratojugal mostly vertical; quadrate with deep concavity in the medial area; paired tuberosities present in the lateral surface of the exoccipital; well-developed vertical crest present on the occipital surface of the supraoccipital; choanae triangular; interchoanal septum present, laminar; parachoanal fossae present, facing medially; palatine bars robust, composed of palatines and ectopterygoids; pterygoid excluded from suborbital fenestra; ectopterygoids take part in the borders of the choanae and the parachoanal fossae; hypophysial-basicranial complex showing two openings; basisphenoid not entirely closing the eustachian foramina; surangular participates in the glenoid fossa.

Material. URC R•73, partially preserved skull (posterior half), articulated with a fragment of the left mandibular ramus, including part of the dentary, posteriormost teeth, angular, surangular and articular (Figures 3-8).

\section{DESCRIPTION AND COMMENTS}

The new specimen of Stratiotosuchus maxhechti, described with comments, is partially damaged and its rostrum is poorly preserved, with extensive deformation and distortion. Nevertheless, comparison with the holotype (DGM 1477-R, Figure 2) allow the recognition of a few rostral features. The rostrum of Stratiotosuchus is robust, longirostrine and oreinrostral, high and showing a strong lateral compression. Unlike the rostral region, the cranial roof is wide laterally. The lateral compression of the snout, and the relative proportions of the rostrum and the remaining skull, certainly granted stereoscopic vision to Stratiotosuchus, a feature which must be related to its hyperpredator habit.

Remaining rostral elements are mostly fragmentary, which include the prefrontals, right lacrimal, right anterior and posterior palpebrals, as well as a small proximal fragment of the right nasal. In the skull table and occipital surface, several elements are preserved, comprising both frontals, postorbitals, parietals, squamosals, supraoccipitals, exoccipitals and basioccipital, with the occipital condyle. The left side shows a better preservation of elements than the right one. In lateral view, it is possible to distinguish the left jugal (fragmented into two), quadrate, part of the quadratojugal and a little fragment of the left maxilla, which bears the last maxillary tooth (Figure 3 ). URC R $\bullet 73$ possesses almost complete palatines, left pterygoid, left ectopterygoid, choanae with complete (parasphenoid) septum and parachoanal fossae and basisphenoid. A fragment of the left dentary and most elements of the caudal section of the left hemimandible were preserved. Only three teeth are present in URC • 73. These crowns show lateral compression and serrated ziphodont carinae, with true denticles.

Skull. In dorsal view, most of the rostral region is missing. The remaining bones are visible along the cranial roof: a small proximal fragment of the right nasal, fragments from the right and left prefrontals, a fragment of the right lacrimal, a fragment 

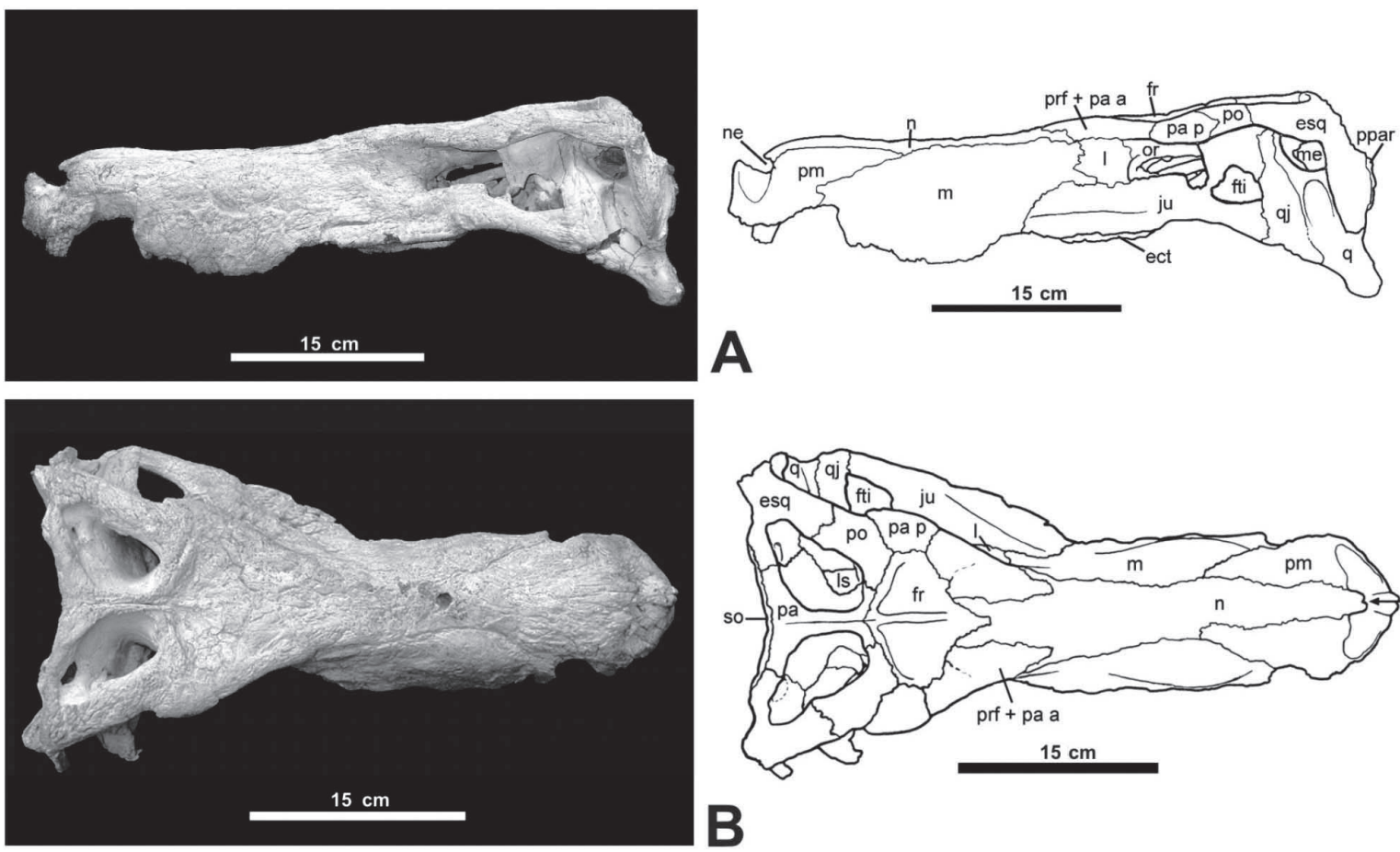

A
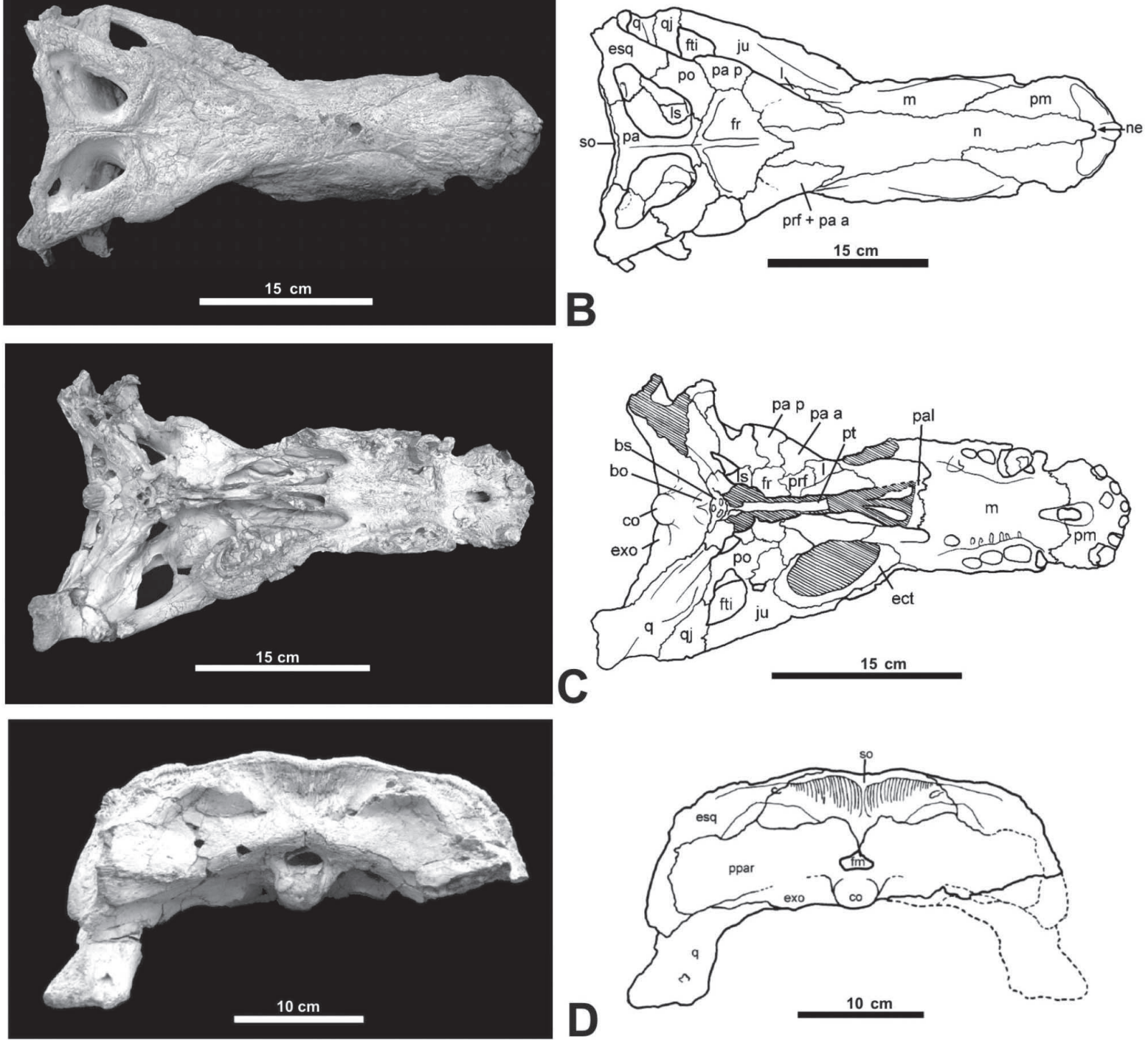

Figure 2. Stratiotosuchus maxhechti, DGM 1477-R, holotype, in left lateral (A), dorsal (B), palatal (C), and occipital (D) views.

of the right anterior palpebral, the right posterior palpebral, as well as frontals, both postorbitals, both parietals narrow, both squamosals, both supraoccipitals, the exoccipitals and a fragment of the right mandibular ramus (Figure 2).

The prefrontals, palpebrals, postorbitals, and parietals do not show significant differences in relation to the holotype. The frontals are fused in a single element in URC • 73 , showing a hexagonal shape, with a pronounced depression on the upper dorsal surface and a single rough longitudinal crest across midline extension, as in the holotype DGM 1477-R (Figure 8).

The upper temporal fenestrae are wide and well developed. They are in a horizontal plane in relation to the skull roof. They show an irregular egg-shape or pear-shape, general triangular outline, with the anterior margins anteriorly convergent. These fenestrae look more rounded than in DGM 1477-R. The measurements are $31 \mathrm{~mm}$ in length for the anteroposterior axis, and $26 \mathrm{~mm}$ for the lateromedial axis. The length-width ratio is different relative to the holotype, scoring 
1.24 for URC R・・73 and 1.58 for DGM 1477-R. These differences are probably due to the allometric growth of this taxon. It should be noticed that the allometric growth of this fenestra indicates the increase of cross-sectional area for muscle attachment on the supratemporal fenestra, which suggests an ontogenetic increase in the absolute and proportional bite force in older individuals.

As mentioned by Riff (2003) for DGM 1477-R, the upper temporal region of URC R $\cdot 73$ exhibits a fenestra and a fossa clearly distinguishing the two. This supratemporal fossa is a platform formed by the parietal, postorbital and squamosal medial expansions, but not for the frontal (Figura 4). Even though Stratiotosuchus shows a great development of the supratemporal fenestra, the frontal reaches the fossa only marginally, as in Baurusuchus and most notosuchians.

The squamosal of URC R・73, as in DGM 1477-R, forms the posterolateral corner on the supratemporal fenestrae. Ventrally, it contacts the anterodorsal quadrate process, and medially, it contacts the parietal, also showing a descending ramus on the occipital surface. The posterolateral margin of the supratemporal fossa in Stratiotosuchus resembles the squamosal rim found in sphenosuchian crocodylomorphs, including Sphenosuchus, Dibothrosuchus, Pseudhesperosuchus, Pedeticosaurus and Saltoposuchus (Sereno \& Wild, 1992). Baurusuchus also shows this border, although less marked. The presence of this feature in advanced Cretaceous mesoeucrocodylians indicates either a parallelism trend or a character reversal (Figure 4).

In lateral view, the best preserved side of the skull is the left, where it is possible to distinguish the left jugal (fragmented into two parts), the left quadrate, the fragmented left quadratojugal and a small portion of the left maxilla which includes the last upper jaw maxillary tooth, the $m x 5$ (Figure 3).

The jugal has the same morphology as seen in DGM 1477$\mathrm{R}$, although the anterior portion is missing. It is not possible to verify the apomorphy on the inferior portion of the anterior jugal branch, which forms a platform process. Although the quadratojugal is broken, it is still possible to recognize that this element is highly verticalized.

As in the holotype, the quadrate is not fenestrated and strongly verticalized. On the quadrate surface, there is a deep oblong concavity that expands dorsally, closing the inferior margin of external otic recess (Figure 3). In fact, among crocodylomorphs, only Baurusuchus has a similar concavity on the lateral surface of the quadrate (Riff, 2003), which constitutes important phylogenetic information on baurusuchids. The external ear region is crushed, but it is possible to distinguish the presence of an otic incisure.

The last tooth of the left maxilla, probably the fifth $(m \times 5)$, is well preserved, showing the typical ziphodont morphology, being labiolingually compressed (Table 1), with mesiodistally serrated carinae. However the serrations on the anterior carina are restricted to the apical region of the crown region, possibly due to abrasion. The measurements are shown in Table 1. Comparison with the holotype DGM 1477-R is impossible, since this specimen does not have preserved tooth crowns.

As in DGM 1477-R, in ventral view, the palatal region of
URC R•73 is highly sculptured. This includes also the palatines and ectopterygoids, not preserved in the holotype. In DGM 1477-R, the medial palatal region, including the palatines, the choanal structure, the ectopterygoids, and the pterygoids, was eroded. URC R $\cdot 73$ possesses almost complete palatines, the left pterygoid, the left ectopterygoid, the choanae with complete parasphenoid septum, the parachoanal fossae, the basisphenoid, the basioccipital, the occipital condyle. The occipital condyle itself is incomplete, with the main body lost (Figure 5).

The choanal region is wide and large, with a rhomboidal/ subtriangular morphology, the apex pointing anteriorly. The triangular/subtriangular choanae are a feature common to Mariliasuchus, Notosuchus, Sphagesaurus and also in the holotype of Baurusuchus pachecoi, DGM 299-R (Andrade et al., 2006). The anterior margin of the choanae is constituted by the palatines, delimiting the medial borders of the suborbital fenestrae (Figure 5). On the posterior end of the palatines (anterior margin of the internal nares) there is a bar, formed by a mesial process of the ectopterygoid and the posterolateral process of the palatine. This bar is extremely wide and thick, forming a robust structure, as in Baurusuchus, but unlike the more delicate bar seen in Notosuchus, Mariliasuchus and Sphagesaurus (Andrade et al., 2006). The pterygoid forms a straight edge on the back of the choanae, giving the characteristic subtriangular shape for the whole structure (Andrade et al., 2006). A robust laminar bony septum is clearly visible, longitudinally crossing the choanal opening, bearing a deep groove across the midline. The choanal floor is very excavated. As in Mariliasuchus, Notosuchus, Baurusuchus and Sphagesaurus, a pair of parachoanal fossae (parachoanal depressions, Andrade et al., 2006) is present on the surface of the pterygoid. These fossae are located lateral to the choanae, on the pterygoid/ectopterygoid suture, facing more medially than ventrally.

In front of the parachoanal depression, a pneumatic channel opens on the ectopterygoid. This channel is present on both sides of the medial anterior portion of skull. It runs across the snout, parallel to the nasal and nasopharyngeal ducts and the pneumatic central cavity, below the nasal duct anteriorly and nasopharyngeal duct posteriorly, but also lateral to the pneumatic central cavity, on the secondary palate.

The ectopterygoid and pterygoid contribute to a sturdy robust tabular transverse process of the pterygoid that is heavily sculptured. The ventral process of the ectopterygoid is preserved, with ornamentation composed of deep striations

Table 1. Tooth measurements $(\mathrm{mm})$ of URC R・73. Abbreviations: AC, anterior carinae; ALJT, anterior lower jaw tooth; BW, basal width (as in Riff \& Kellner, 2001); dent/mm, number of denticle per mm; FABL, fore-after basal length; PC, posterior carinae; PLJT, posterior lower jaw tooth; $\mathbf{T C H}$, crown height.

\begin{tabular}{|c|c|c|c|c|c|}
\hline & FABL & $\mathrm{TCH}$ & BW & $\begin{array}{c}\text { dent } / \mathrm{mm} \\
\mathrm{AC}\end{array}$ & $\begin{array}{c}\text { dent } / \mathrm{mm} \\
\text { PC } \\
\end{array}$ \\
\hline$m \times 5$ & 11.1 & 24.3 & 8.8 & $3-3.5$ & 2.5 \\
\hline $\begin{array}{c}\text { ALJT } \\
{\left[d^{\prime}\left(8-9^{\text {th }}\right) \text { ?] }\right.}\end{array}$ & 11.2 & 18.5 & 8.0 & 3 & 2.5 \\
\hline $\begin{array}{c}\text { PLJT } \\
\text { [d"' }\left(9-10^{\text {th }}\right) \text { ?] }\end{array}$ & 5.8 & 6.5 & 4.6 & 0 & 3 \\
\hline
\end{tabular}



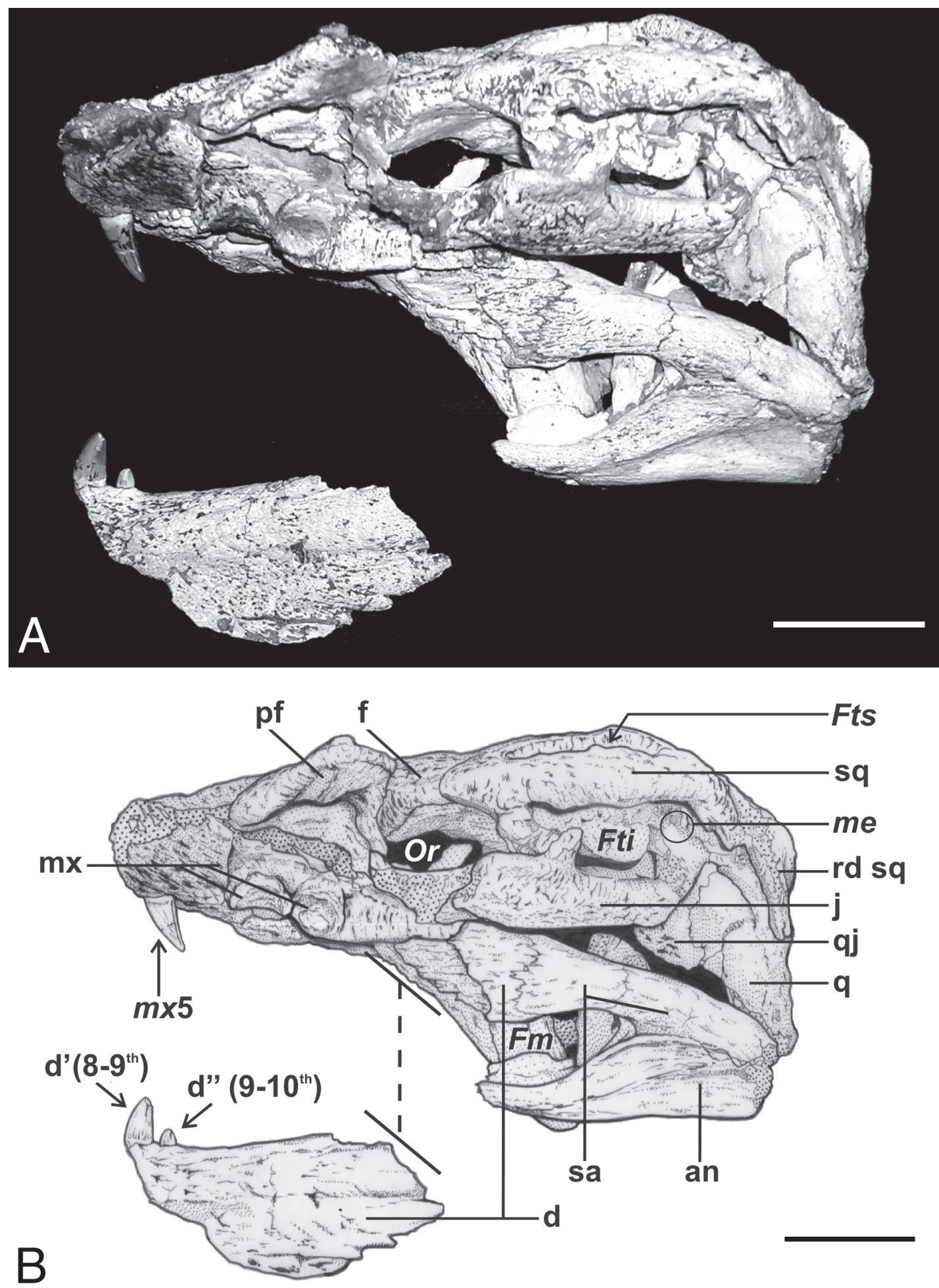

Figure 3. Stratiotosuchus maxhechti, URC R・73, photograph (A) and drawing (B) in left lateral view. Scale bars $=5 \mathrm{~cm}$.

and irregular grooves, an important surface for the attachment of the strong jaw adductor musculature. The pterygoids are fused on the posterior choanal area. They form a pair of relatively distinct small pterygoidean bullae on the posterior portion, which are pneumatic elements of the structure (Figure 5). The pterygoid wings are mostly vertical, as in Baurusuchus and somewhat similar to what can be seen in eusuchians.
This is related to the development of strong adductor muscles in this region. These muscles have been associated with the extremely fast snapping jaw closure of extant eusuchians (Olson, 1961; Iordansky, 1973; Schumacher, 1973), and must have allowed Stratiotosuchus (as Baurusuchus) to deliver a strong and fast bite to their prey.

The basisphenoid and the basicranium region face 

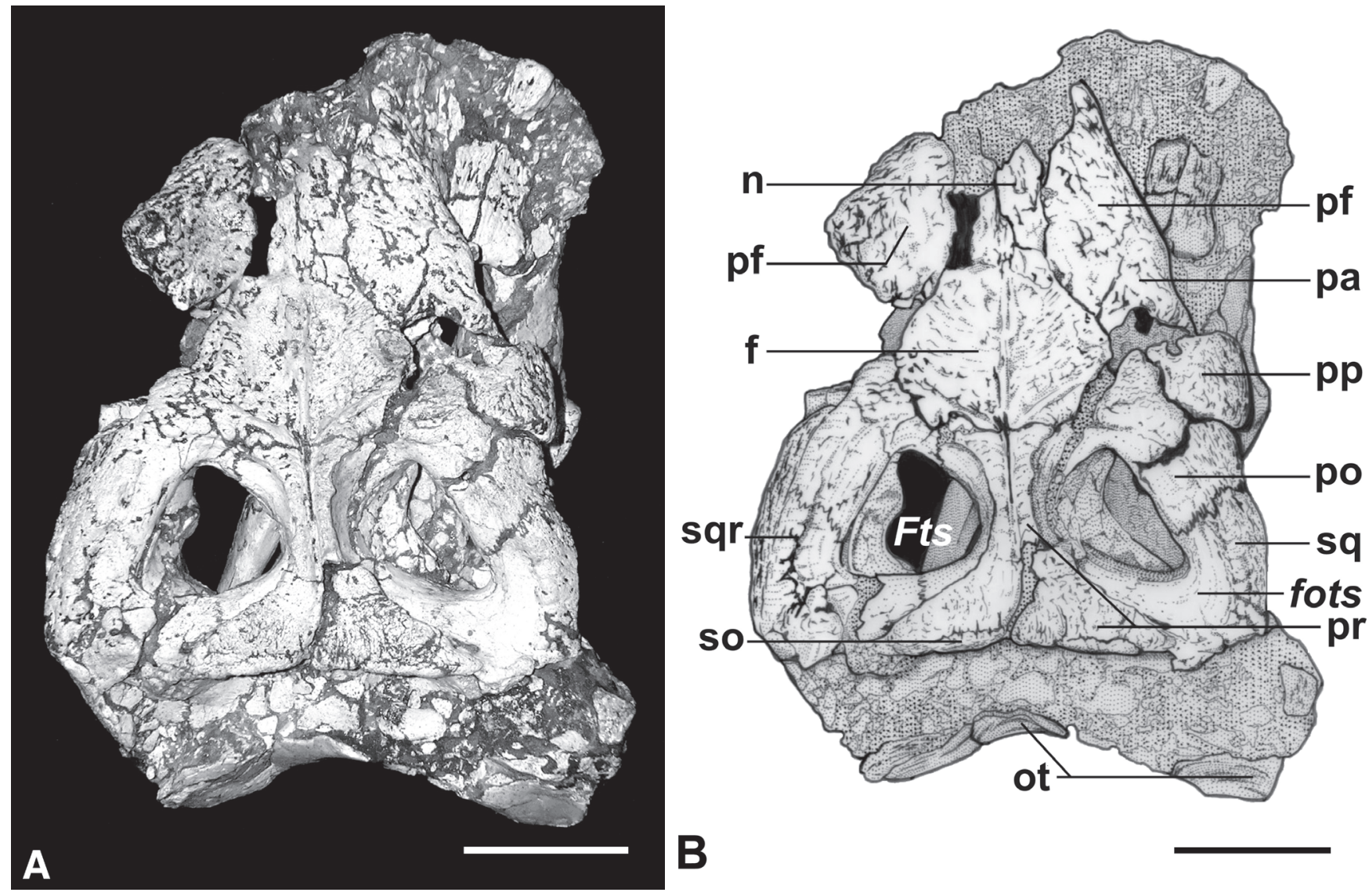

Figure 4. Stratiotosuchus maxhechti, URC R・73, photograph (A) and drawing (B) in dorsal view. Scale bars $=5 \mathrm{~cm}$.

posteroventrally, both in the holotype and URC R・73. The basicranium is anterodorsally inclined about $60^{\circ}$, following the basioccipital ventral plane (Riff, 2003). The occurrence of this morphology in URC R・73 confirms this feature does not result from taphonomic processes (Figures 5, 6), and also indicates this characteristic is not likely to change through the late ontogenetic stages of Stratiotosuchus. The strong inclination of the basicranium is similar to the condition found in protosuchians, basal mesoeucrocodylians, notosuchians, thalattosuchians, sebecosuchians (Andrews, 1919; Benton \& Clark, 1988; Riff, 2003). On the contrary, the basicranium in adult eusuchians faces posteriorly (Benton \& Clark, 1988).

The basisphenoid is well preserved in palatal view. However, its dorsal portion that contacts the laterosphenoid and quadrate ramus of the pterygoid is damaged, so that it is not possible to identify the basisphenoid rostrum (cultriform process). In this area, the laterosphenoid also contacts the quadrate ramus of the pterygoid, which could not be observed in URC R.73, due to the damage. The lateral basisphenoid processes do not enclose the lateral eustachian foramina (Riff, 2003). The basipterygoid process of the basisphenoid is clearly identifiable, although missing in the holotype, and none of the external foramina is visible on this process. In DGM 1477-R, the channel system is exposed, but the openings not. The hypophysial-basicranial fenestra is composed of two openings, the anterior (basisphenoid additional foramen) leading into the basisphenoid sinus, and the posterior (intertympanic foramen) leading into the basisphenoidal sinus, situated between the basisphenoid/basioccipital suture. Therefore, Stratiotosuchus maxhechti has two openings in the basisphenoid to the eustachian system (Figure 5), not three, as proposed by Riff (2003). This feature resembles those observed in the posthatchling crocodylians. It is a primitive condition of the hypophysial-basicranial fenestra system in archosaurs, which has these two medial openings (Tarsitano, 1985).

The occipital region is broken and fragmented, with the development of a horizontal fracture and lateral displacement of the elements. Nevertheless, supraoccipitals and exoccipitals are still identifiable, as the left paraoccipital process is visible.

The basioccipital is well preserved, with winged aspect and posteroventrally oriented. It is not possible to observe the suture between the basioccipital and the exoccipital, which is present in DGM 1477-R. The posterior left carotid foramen is visible on the basioccipital/quadrate contact, but the right one is closed by deformational processes. A pair of basioccipital tuberosities, one on each side, is present below and lateral to the occipital condyle, with a low crest between them (Figures 5, 6).

In URC R $\cdot 73$, only the base of the occipital condyle (a massive structure) is preserved (Figure 6). The diameter of the base of the condyle allows the appreciation of differences in size between the holotype $(27 \mathrm{~mm})$ and URC R $\bullet 73$ (19.3 

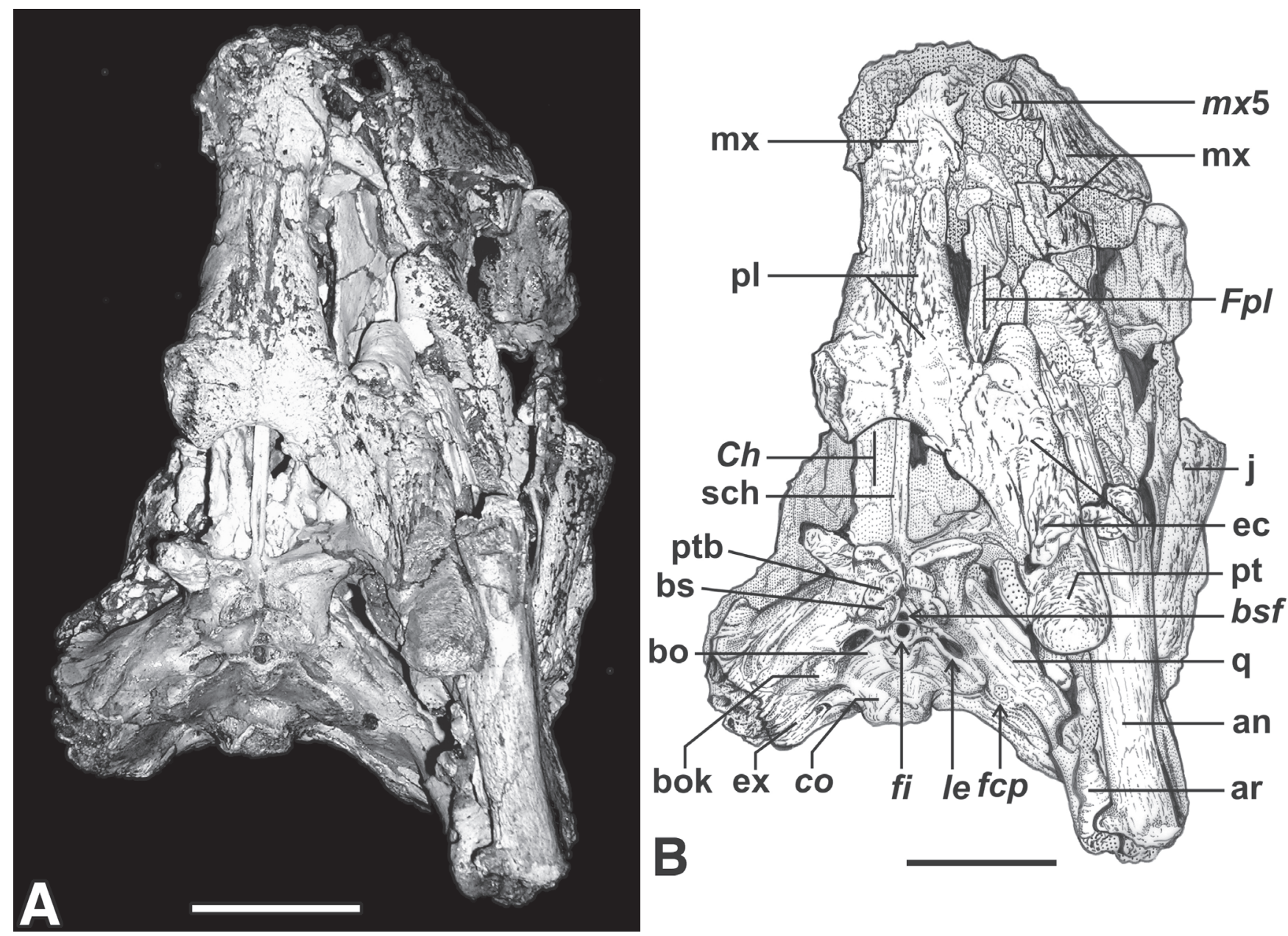

Figure 5. Stratiotosuchus maxhechti, URC R・73, photograph $(\mathbf{A})$ and drawing $(\mathbf{B})$ in palatal view. Scale bars $=5 \mathrm{~cm}$.

$\mathrm{mm})$. The posterior region and the occipital area are broken and fragmented, where only a few elements, such as the supraoccipitals and exoccipitals, are identifiable. The left paraoccipital process is visible and the foramen magnum exhibits some deformation (Figure 6).

The supraoccipitals are well developed. Contrary to the condition in the holotype, they are not fused, which is possibly related to the ontogenetic stage of URC R•73, presumably a sub-adult specimen. They are slightly concave and ornamented on the occipital surface by descending striations, an insertion area for nuchal-cervical muscles, with a medial crest projecting from the surface (Figure 6).

The exoccipitals show a small degree of fragmentation, but in general their surface is smooth. On the ventral portion of the right side are the vagus foramen and cranial passages for nerves IX, X and XI. There is a small foramen below the vagus foramen, allowing another passage to the IX nerve ramification. The passage to the XII cranial nerve is located lateromedially to the foramen magnum (Figure 6). In the holotype, this region is not as well preserved and these features are hardly identifiable.

As in DGM 1477-R, the opisthotic (paroccipital process) of URC R•73 is wide and slightly concave, exhibiting strong horizontal striations on the ventral portion, the right side of the referred specimen being lost. The ventral portion of the process limits dorsally the cranioquadrate passage.

Mandible. The mandible is represented by the posterior portion of the left ramus, which is preserved in articulation with the skull. Only a small medial posterior fragment of the dentary is preserved, holding the last two lower jaw teeth. The anteriormost tooth is fragmented at the base and top of the crown, but its structure is still preserved. The dentary is deep and robust, with a relatively short tooth row, which is reduced in number (Figures 3-7). The ventral border of the dentary is expanded on both surfaces, the external laterally and the ventral medially.

The left surangular and angular are almost complete. The ornamented surangular does take part in the skull/mandible articulation, but makes no significant contribution to the glenoid fossa. These characters are not preserved in the holotype, constituting a remarkable contribution to a better knowledge of the Stratiotosuchus maxhechti osteology (Figure 8). On the external posterior surface of the angular, the typical ornamentation is absent, and the area shows a smooth concavity. This bone shows the posterior ramus to be straight, with little convexity on the end (Figures 3, 6).

The left articular was not preserved in the posterior region of this mandibular ramus. Thus, the retroarticular 

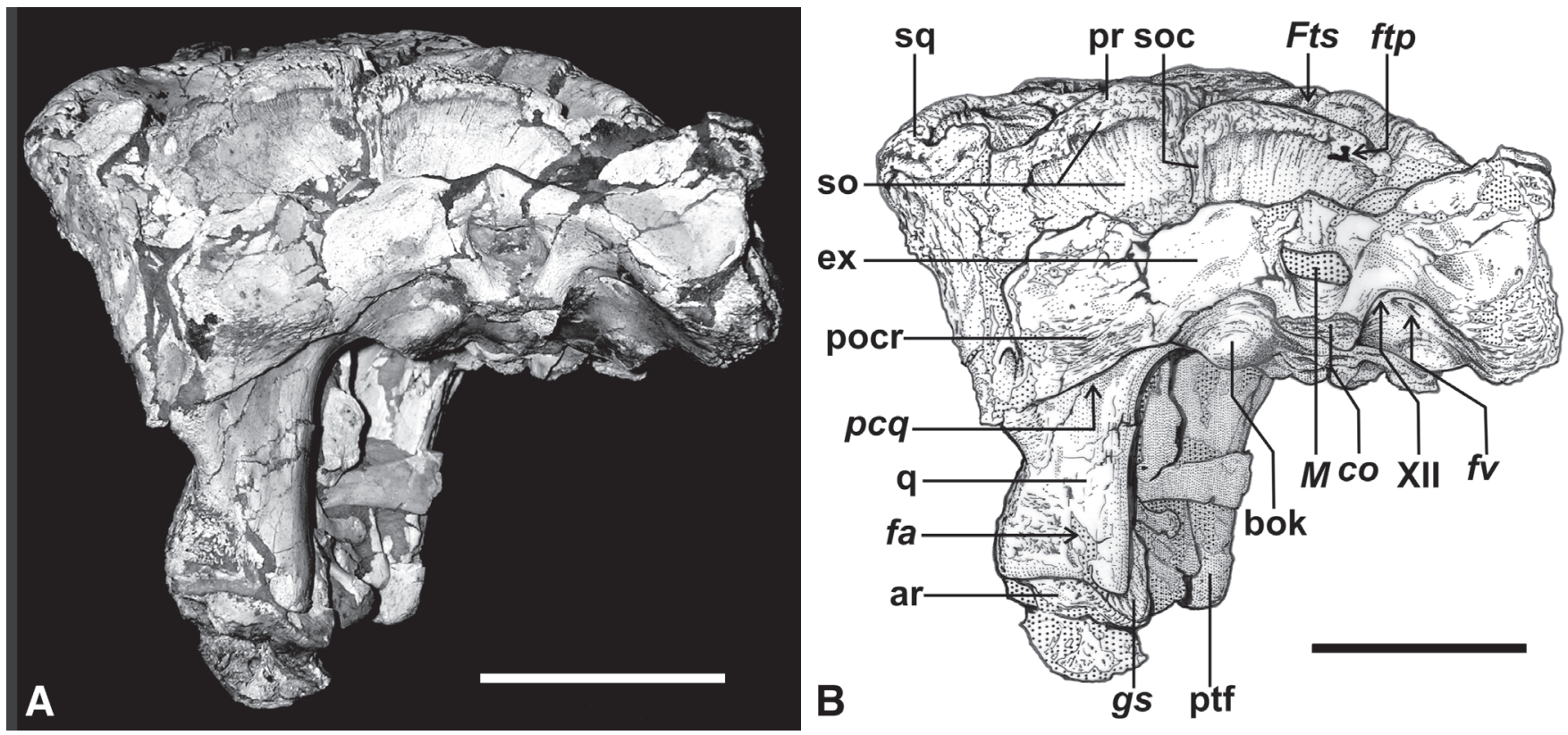

Figure 6. Stratiotosuchus maxhechti, URC R・73, photograph $(\mathbf{A})$ and drawing $(\mathbf{B})$ in occipital view. Scale bars $=5 \mathrm{~cm}$.

process is missing. Nevertheless, the glenoid fossa is present and visible from the posterior and internal sides (Figure 6). It is inclined as in Baurusuchus, facing dorsomedially. A small portion of the splenial is present on the fragment, which bears a dentary fraction, visible from the internal side (Figure 7).

Dentition. The dentition of Stratiotosuchus is poorly known. Only ten isolated teeth from DGM 1477-R were reasonably preserved: four complete and six fragments of bases and crowns (Riff, 2003). In the holotype, all maxillary teeth are partially preserved, but broken in different crown regions, with a few of them maintaining the enamel layer. Only two dentary teeth are partially preserved, lacking most of the crown; they show the ziphodont (or theropodomorph) condition, typical of highly predaceous mesoeucrocodylians, with the following dental formula: $p m(3)+m x(5) / d(9-10$ ?) (Campos et al., 2001; Riff, 2003).

Due to this limited information, the description of new dental material of Stratiotosuchus becomes especially meaningful. As observed previously, the dentition of Stratiotosuchus is ziphodont (Campos et al., 2001; Riff, 2003), typical of highly predaceous mesoeucrocodylians. In URC R•73, the dentition is slightly heterodont, because of the last mandibular tooth. However, it is also anisometric, with significant variation in size but small morphologic differences. There are some distinctions in tooth development, but functionally they are all caniniforms. Only three teeth are preserved, with theropodomorph-like crowns, all on the left side of the specimen: a well developed last maxillary tooth and two posterior dentary teeth. They show a reasonably good preservation, although crowns are not always complete. All of them have fine vertical (basal-apical) striae, with microscopic transversal strings (Figure 9).

Both lingual and labial surfaces are smooth and unornamented (Figure 9). This can be better seen with the use of SEM, on the isolated tooth. These crowns show the typical ziphodont morphology (Langston, 1975; Prasad \& Broin, 2002; Andrade \& Bertini, 2005), as in Baurusuchus (Riff \& Kellner, 2001): (a) lateral compression (b) both carinae serrated, with chisel-like denticles (Figure 9); and (c) crown distally curved.

The serrations on the anterior carinae of $m \times 5$ are restricted to the apical crown only. Albeit the serrated condition was observed in only one tooth and may be the result of abrasion, this could constitute a new distinctive character of Stratiotosuchus (Figure 9). Unfortunately, comparison with the holotype is impossible, since DGM 1477-R does not have preserved tooth crowns. New specimens are necessary to determine if posterior maxillary teeth truly lack carinae at the base of the crowns and if this condition is limited to posterior maxillary teeth or applies to other elements.

The first preserved dentary tooth is possibly the eighth element $(d 8)$ of the lower series. The crown was originally broken, but the tooth is well developed. This element also lacks the crown apex, but shows a morphology coincident with the maxillary tooth. In this element, both the mesial and distal carinae extend from the base to the crown apex, unlike the mesial carina of the last maxillary tooth.

The posteriormost dentary tooth is possibly the nineth $(d 9)$ of the series. It is much smaller than the preceding tooth or the maxillary one (measurements in Table 1). It also lacks the crown apex and any sign of evident distal inclination. This tooth also shows the distal carina, but seems to lack the mesial one. However, it must be noted that both elements, the last dentary and last maxillary teeth, seem to lack at least the basal and the middle sections of the mesial carina, which could be restricted to the apical part of the crown, or even absent in $d 9$ (Figure 9). 


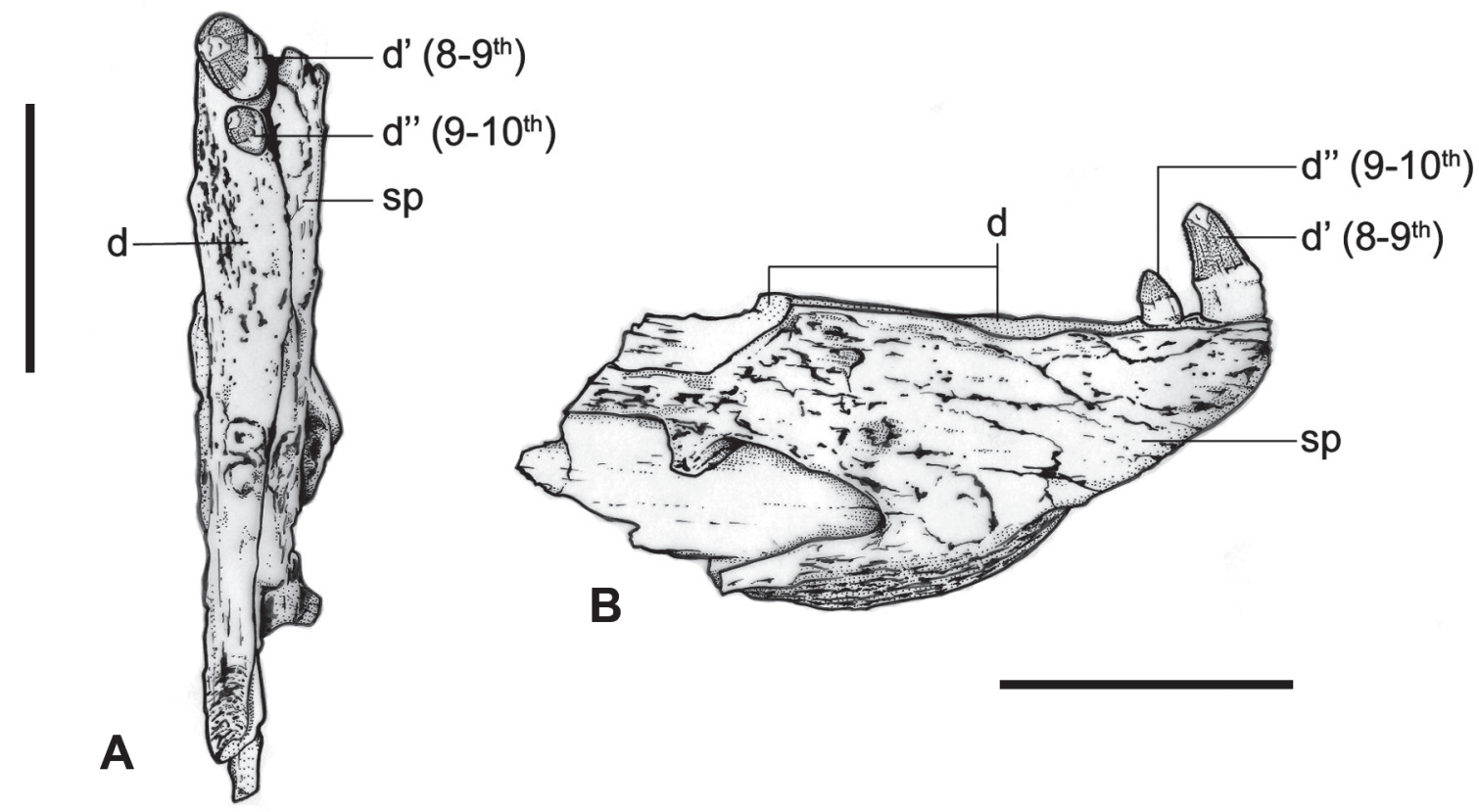

Figure 7. Stratiotosuchus maxhechti, mandible fragment of URC R•73, in oclusal (A) and lateral internal $(\mathbf{B})$ views. Scale bars $=5 \mathrm{~cm}$.

\section{FINAL CONSIDERATIONS}

All specimens of $S$. maxhechti, came from the Adamantina Formation. DGM 1477-R and MCT 1714-R came from the Irapuru region, in southwestern São Paulo State; URC R•73 was collected in the Monte Alto area, in the northern-central portion of the same state (Figure 1). This geographic distribution could stimulate some important and significant discussions.

Some aspects concerning paleobiogeography, biochronology, biostratigraphy and paleoecology of the Adamantina Formation are controversial. Problems exist mainly because of the lack of index fossils. The presence of $S$. maxhechti in different localities of the Adamantina Formation allows us to recognize the correlation between these relatively distant geographic regions. The $S$. maxhechti occurrences in the Adamantina Formation, in the Irapuru and Monte Alto regions, indicate that these localities are of similar age, and could belong to a similar or even the same stratigrapic level. The paleoecological depositing conditions also should have been the same in these localities, based on the shared occurrence of this species.

This is the second occurrence of $S$. maxhechti in the Adamantina Formation from the Bauru Basin, the second skull and the third specimen of this species. These patterns of lithostratigraphic and paleobiogeographic distributions could lead to two different interpretations. The first one considers the possibility that, in the interior of the basin, semi-arid weather conditions reigned, with hot temperatures and sporadic dryness, in a fluvial meandering paleoenvironment. There could have occurred great sand banks and dunes, delimiting the fluvial channels. In the northern, northwestern and southwestern areas of the Bauru Basin, the weather conditions allowed regions with strips of forest and open vegetation, where a higher humidity should have provided favorable conditions to the survival of several species, including Crocodyliformes and Titanosauria (Santucci \& Bertini, 2001). In this context, most faunistic elements should have occupied areas across the borders of the Bauru Basin, with sporadic migratory movements through the central area. These occurrences corroborate the hypothesis by Fernandes (1998), of a semiarid, dry and hot central region of the basin, bordered by humid regions. The second explanation to the non-continuous geographic distribution of specimens of Stratiotosuchus include the difficult access and scarcity of outcrops in some areas, presence of extensive vegetation and/or difficulties to access certain localities and the scarcity of outcrops, which affect several areas of the Bauru Basin. Due to this situation, the prospective and collecting efforts are concentrated in the regions of easier access, such as Flórida Paulista, General Salgado, Jales, Peirópolis, Presidente Prudente. As a result, the lack of occurrences in the interior of the Bauru Basin may be interpreted as a sampling artifact and perhaps should not be related to paleoclimatic conditions, or the type of vegetation prevailing in the area during the Upper Cretaceous, or natural water reservoir during deposition process. Stratiotosuchus maxhechti is a derived mesoeucrocodylian, as evidenced mainly by an oreinorostral snout, reduced dental number and specific choanal morphology. URC $\mathrm{R} \cdot 73$ provides important additional characteristics, such as: (i) detached squamosal posterolateral border of the supratemporal fossa, which is present in Baurusuchus, but less marked in $B$. pachecoi Price, 1945 (DGM 299-R) and B. salgadoensis Carvalho et al., 2005; (ii) two openings on the hypophysialbasicranial complex; and (iii) basisphenoid not entirely closing the lateral eustaquian foraminae. These characters are regarded here as plesiomorphic, as they occur in other more basal species of crocodylomorphs. 

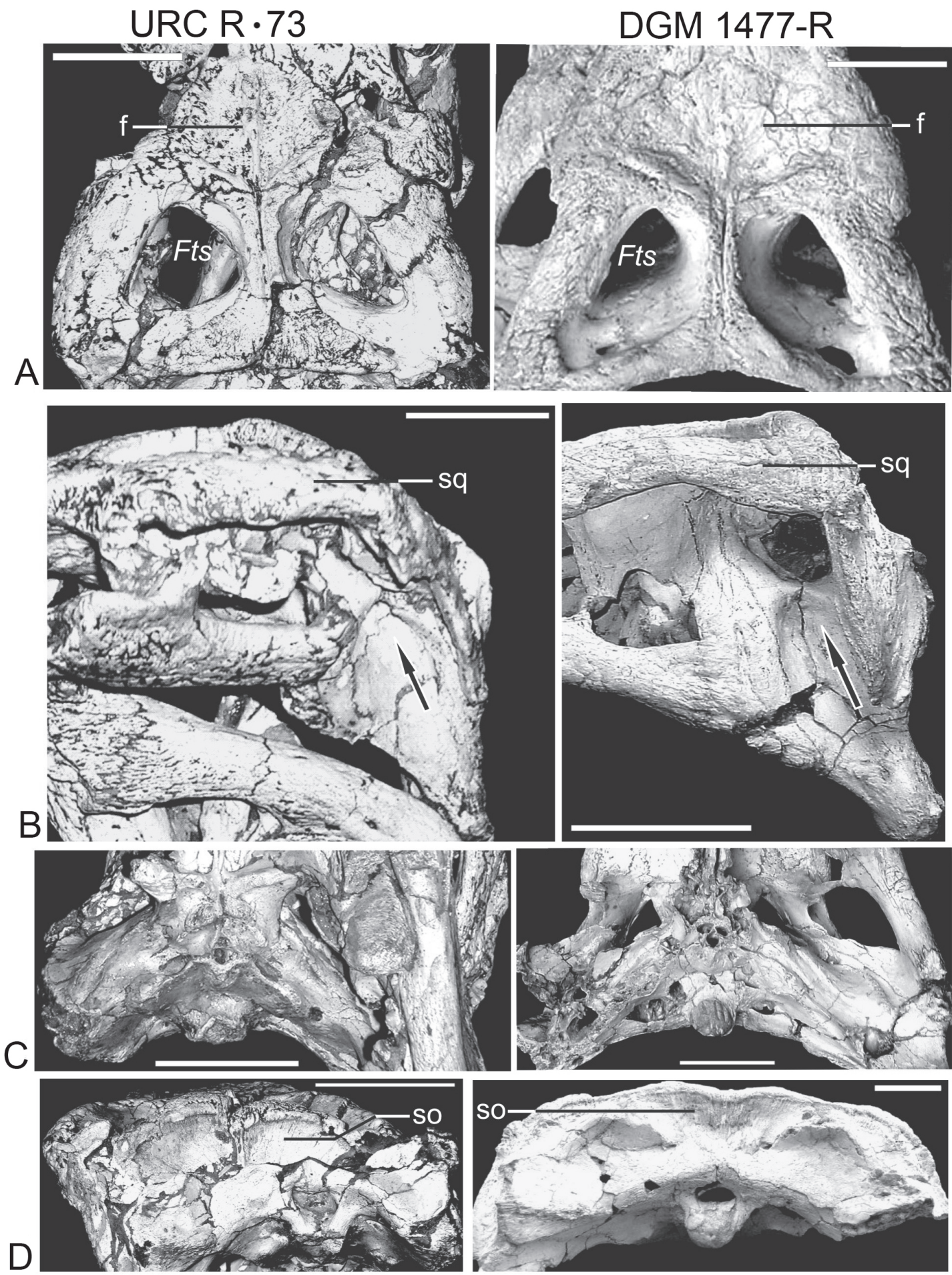

Figure 8. General similarity between URC R•73 (left) and DGM 1477-R (right)in dorsal (A), lateral (B), basicranium (C), and occipital (D) views. Scale bars $=5 \mathrm{~cm}$.

Several features of the palate and choanae are similar to those of derived notosuchians, such as Notosuchus, Mariliasuchus and Sphagesaurus, but not with more basal members of this lineage (e.g., Malawisuchus, Uruguaysuchus). However, the general characteristics of the skull and dentition allow the recognition of Stratiotosuchus as a baurusuchid (Campos et al., 2001; Riff, 2003). The typical baurusuchid morphology provides meaningful paleoecological information. The size, orientation and robustness of the pterygoid wings, and the enlargement of the supratemporal fenestra are clear indicators of the importance of associated adductor muscles. As for Baurusuchus, the elongated snout, ziphodont dentition with hypertrophied elements, and the powerful set of muscles 

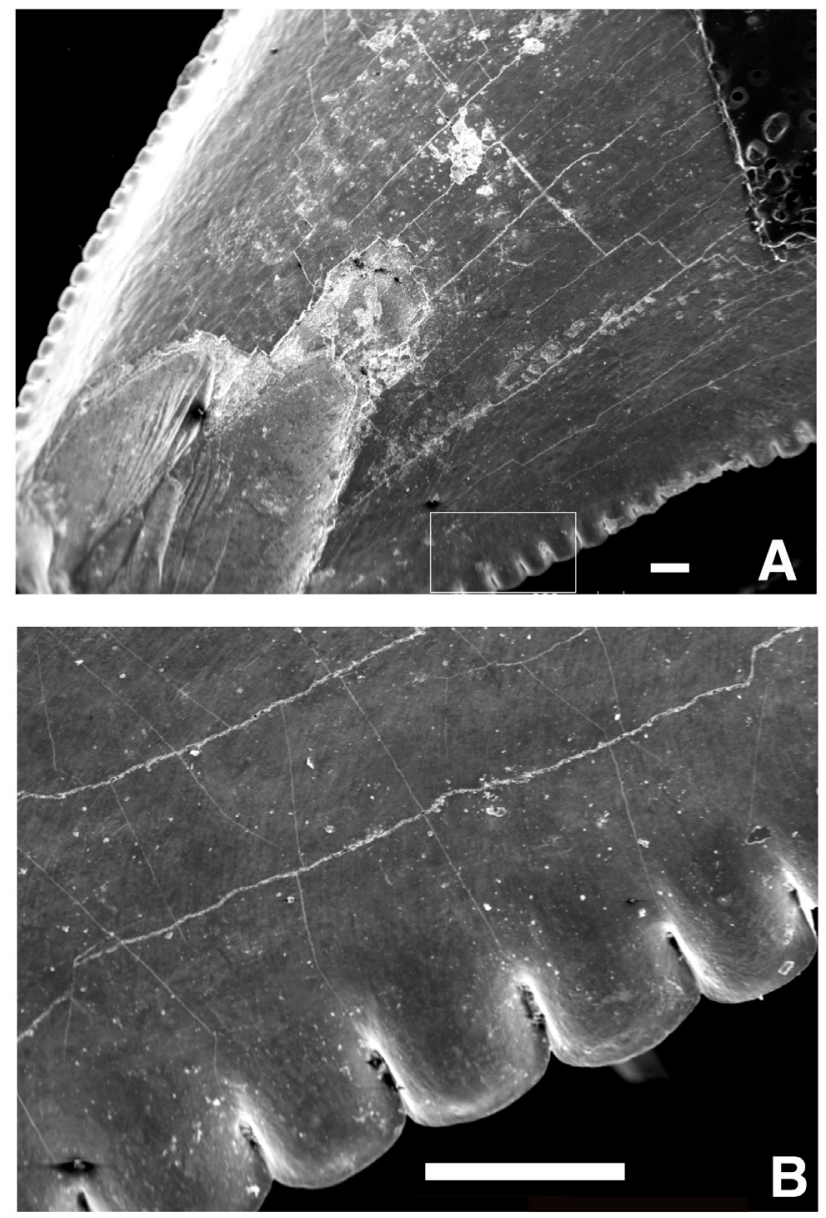

Figure 9. SEM of the dentary tooth [d'(8-9 th $)]$ from URC R・73. A lateral suface, showing the typical ziphodont pattern: both serrated carinae, apex slightly posteriorlly curved, and lateral compression; B, detail of the denticles. Scale bar $=0.5 \mathrm{~mm}$.

connected to the supratemporal/mandibular fenestrae, probably enabled Stratiotosuchus to deliver a wide, powerful and prolonged bite.

Such characteristics allow the recognition of Stratiotosuchus as a hyperpredator species, capable of killing large-sized prey. The reduced dentition, concentrated in the anterior part of the snout, is consistent with preference for large-sized prey, as the long snout and powerful pterygoid muscles help build momentum. This might be useful to capture small-sized prey, but is a requirement for biting large-sized prey. A reduced theropodomorph dentition may also be found in a few other mesoeucrocodylians, such as Bergisuchus. Despite the general development of convergences among highly predaceous species of vertebrates, this kind of dentition differs substantially from the one found in other groups of terrestrial predaceous crocodylomorphs (e.g., peirosaurids, trematochampsids, sebecids), which had more generalized dentition. These differences could indicate niche partition for these groups, where baurusuchids preferred large-sized prey and other ziphodont species (e.g., Sebecus, Hamadasuchus, Peirosaurus) fed on a broader range of smallto medium-sized prey.

The Adamantina Formation in São Paulo State has yielded fossils of various species and groups that lived during the
Late Cretaceous, in the same geographic area (Bertini et al., 1993). Fossil content includes titanosaurs, the largest possible prey in that particular environment, and at least another predaceous mesoeucrocodylian, the peirosaurid Itasuchus. It is thus possible that baurusuchids and peirosaurids shared the same habitat during the Upper Cretaceous of São Paulo State, by means of niche partition.

The specimen described here provides information on the anatomy of the species and the evolution of Crocodyliformes. Anatomic comparisons are consistent with a close proximity with Baurusuchus, but Stratiotosuchus also shares characters in common with derived notosuchians. The SEM study of URC R $\cdot 73$ tooth provides reliable information on dental morphology and its recognition as a ziphodont species. URC R $\bullet 73$ also indicates possible new and previously unknown autapomorphic features for the dentition of Stratiotosuchus, increasing the differences for this mesoeucrocodylian compared to Baurusuchus. The lack of fusion of the skull elements and changes in the proportional size of the fenestra, when compared with the holotype, provides ontogenetic information on Stratiotosuchus.

The provenance of URC $\mathrm{R} \cdot 73$, and the revised lithostratigraphic and paleobiogeographic distributions of Stratiotosuchus, provide evidence for a correlation between two geographically distant localities within the Bauru Basin. These also allow the formulation of a new hypothesis on the paleoecology of the Bauru Basin.

Morphofunctional characteristics of the baurusuchids, confirmed and complemented by the description of this new specimen, indicate a specialized predaceous habit for the group, allowing the recognition of a possible niche for this type of fossil crocodyliform. Due to its phylogenetic, stratigraphic and paleobiogeographic importance, Stratiotosuchus maxhechti is considered an important species of crocodyliform from the Late Cretaceous of the Bauru Basin.

\section{ACKNOWLEDGMENTS}

We are grateful to A. W. Kellner and D. Riff (MNRJ); D. de A. Campos and R. C. T. Cassab (DNPM); Z. B. Gasparini, M. Reguero and S. Bargo (MLP); and T. S. Marinho for allowing the access to the materials. We also thank $\mathrm{M}$. Longhim (UNESP) for SEM images of the zifodont teeth; R. $M$. Santucci for comments and revision on the early version of the manuscript; M. T. Young and P. Gill, for helpful assistance with English translation; and the paleontological crew from the Núcleo de Evolução e Paleobiologia de Vertebrados (UNESP Rio Claro). Images of DGM 1477-R (Figures 2,8) are courtesy of D. Riff; drawings of the Figures 3-6 were made by A.E.P. Pinheiro. Financial support for this study was provided through grants from CAPES and CNPq (MBA, 200381/007-8). This contribution was previously presented in the II Congresso Latino-Americano de Paleontologia de Vertebrados, held in August, 2005, in Rio de Janeiro, Brazil. 


\section{REFERENCES}

Andrade, M.B.; Bertini, R.J. \& Pinheiro, A.E.P. 2006. Observations on the palate and choanae structures in Mesoeucrocodylia (Archosauria, Crocodylomorpha): Phylogenetic Implications. Revista Brasileira de Paleontologia, 9(3):323-332.

Andrade, M.B. \& Bertini, R.J. 2005. Morphology of the dental carinae in Mariliasuchus amarali (Metasuchia) and the pattern variation among fossil Crocodylomorpha. In: CONGRESSO LATINO-AMERICANO DE PALEONTOLOGIA DE VERTEBRADOS, 2, 2005. Boletim, Rio de Janeiro, MNRJ, p. 2526.

Andrews, C.W. 1913. A Descriptive Catalogue of the Marine Reptiles of the Oxford Clay Based on the Leeds Collection in the British Museum (Natural History), London-Part II. London, Taylor \& Francis, 206 p.

Batezelli, A.; Saad, A.R.; Etchebehere, M.L.C.; Perinotto, J.A.J. \& Fulfaro, V.J. 2003. Análise estratigráfica aplicada à Formação Araçatuba (Grupo Bauru-KS) no Centro-Oeste do Estado de São Paulo. Geociências, 22:5-19.

Benton, M.J. \& Clark, J.M. 1988. Archosaur Phylogeny and the relationships of the Crocodylia. In: M.J. Benton (ed.) The Phylogeny and Classification of the Tetrapods, Clarendon Press, 1:295-338.

Bertini, R.J. 1993. Paleobiologia do Grupo Bauru, Cretáceo Superior continental da Bacia do Paraná, com ênfase em sua fauna de amniontas. Programa de Pós-Graduação em Geologia, Universidade Federal do Rio de Janeiro, Doctoral Dissertation, $497 \mathrm{p}$.

Bertini, R.J.; Santucci, R.M.; Ribeiro, L.C.B. \& Arruda-Campos, A.C. 2000. Aeolosaurus (Sauropoda, Titanosauria) from Upper Cretaceous of Brazil. In: JORNADAS ARGENTINAS DE PALEONTOLOGIA DE VERTEBRADOS, 16, 2000. Actas, San Luis, p. 6.

Campos, D.A. \& Suarez, J.M. 1988. Um novo Baurusuchidae (Reptilia, Crocodylia) do Cretáceo Superior do Estado de São Paulo. Anais da Academia Brasileira de Ciências, 27:412.

Campos, D.A.; Suarez, J.M.; Riff, D. \& Kellner, A.W. 2001. Short note on a new Baurusuchidae (Crocodyliformes, Metasuchia) from the Upper Cretaceous of Brazil. Boletim do Museu Nacional, Nova Série Geologia, 57:1-7.

Carvalho, I.S.; Arruda-Campos, A.C. \& Nobre, H. 2005. Baurusuchus salgadoensis, a new Crocodylomorpha from the Bauru Basin (Cretaceous), Brazil. Gondwana Research, 8(1):1130.

Fernandes, A.L. 1998. Estratigrafia e evolução geológica da parte Oriental da Bacia Bauru (Ks, Brasil). Programa de Pós-Graduação em Geologia Sedimentar, Universidade de São Paulo, São Paulo, Doctoral Dissertation, 216 p.

Fernandes, A.L. \& Coimbra, M.A. 1996. A Bacia Bauru (Cretáceo Superior, Brasil). Anais da Academia Brasileira de Ciências, 68:195-205.

Gasparini, Z.; Chiappe, M.L. \& Fernandez, M. 1991. A new Senonian Peirosaurid (Crocodylomorpha) from Argentina and a synopsis of the South American Cretaceous Crocodylians. Journal of Vertebrate Paleontology, 11:316-333.

Gobbo-Rodrigues, R.S.; Santucci, R.M. \& Bertini, R.J. 2001. Considerações sobre a idade da Formação Marília (Grupo Bauru, Cretáceo Superior) na região de Peirópolis, Estado de Minas Gerais. In: CONGRESSO BRASILEIRO DE PALEONTOLOGIA, 17, 2001. Boletim de Resumos, Rio Branco, p. 48.
Iordansky, N.N. 1973. The skull of the Crocodylia. In: C. Gans \& S. T. Parsons (eds.) Biology of the Reptilia, Academic Press, p. 201-264

Kellner, A.W. 1998. Panorama e perspectiva do estudo de répteis fósseis no Brasil. Anais da Academia Brasileira de Ciências, Rio de Janeiro, 70:647-676.

Langston, W. 1975. Ziphodont crocodyles:Pristichampsus vorax (Troxell), a new combination, from the Eocene of North America. Fieldiana-Geology, 33:291-314.

Olson, E.C. 1961. Jaw mechanisms: rhipidistians, amphibians, reptiles. American Zoologist, 1:205-215.

Prasad, G.V.R. \& Broin, F. 2002. Late Cretaceous crocodyle remains from Naskal (India):comparisons and biogeographic affinities. Annales de Paléontologie, 88:19-71.

Price, L.I. 1945. A new reptil from the Cretaceous of Brazil. Notas Preliminares Estudos, Divisão Geologia Mineralogia, 25:1-8.

Riff, D. 2003. Descrição morfológica do crânio e mandíbula de Stratiotosuchus maxhechti (Crocodylomorpha, Cretáceo Superior do Brasil) e seu posicionamento filogenético. Universidade Federal do Rio de Janeiro, Master Thesis, 144 p.

Riff, D. \& Kellner, A.W. 2001. On the dentition of Baurusuchus pachecoi Price (Crocodyliformes, Metasuchia) from the Upper Cretaceous of Brazil. Boletim do Museu Nacional, Nova Série, Geologia, 59:1-15.

Santucci, R.M. \& Bertini, R.J. 2001. Distribuição paleogeográfica e biocronológica dos titanossauros (Saurischia, Sauropoda) do Grupo Bauru, Cretáceo Superior do sudeste brasileiro. Revista Brasileira de Geociências, 31:307-314.

Schumacher, G.-H. 1973. The head muscles and hyolaryngeal skeleton of turtles and crocodylians. In: C. Gans \& S.T. Parsons (eds.) Biology of the Reptilia, Academic Press, p. 101-199.

Sereno, P.C. \& Wild, R. 1992. Procompsognathus: theropod, "thecodont" or both? Journal of Vertebrate Paleontology, 12(4):435-458.

Simpson, G.G. 1937. New reptiles from the Eocene of South America. American Museum Novitates, 927:3 p.

Smith, J.B. \& Dodson, P. 2003. A proposal for a stantdard terminology of anatomical notation and orientation in fossil vertebrate Dentitions. Journal of Vertebrate Paleontology, 23(1):1-12.

Soares, P.C.; Landim, P.M.B.; Fulfaro, V.J. \& Sobreiro Neto, F.A. 1980. Ensaio de caracterização estratigráfica do Cretáceo no Estado de São Paulo: Grupo Bauru. Revista Brasileira de Geociências, 10:177-185.

Tarsitano, S.F. 1985. Cranial metamorphosis and the origin of the Eusuchia. Neues Jahrbuch für Geologie und Paläontologie, Abhandlungen, 170(1):27-44.

Walker, D.A. 1970. A revision of the Jurassic reptile Hallopus victor (Marsh), with remarks on the classification of crocodyles. Philosophical Transactions of the Royal Society of London, 257 B:323-372.

Whetstone, N.K. \& Whybrow, J.P. 1983. A "cursorial” crocodylian from the Triassic of Lesotho (Basutoland), Southern Africa. Occasional Papers of the Museum of Natural History of University of Kansas, 106:1-37.

Received in February, 2007; accepted in February, 2008. 